\title{
The Effective Spatial Qualities on Urban Tourism in Iran Focusing on Social Factors
}

\author{
Kambiz Razavi ${ }^{1}$, Filipe Themudo Barta ${ }^{2}$ and Elham Amini ${ }^{3}$ \\ ${ }^{1}$ Member of the Board of Directors, and the chairman of Professional Group of Traffic in Construction Engineering Organization of Tehran \\ Province: Student of Urban Planning in Universidade Lusofona, Lisbon \\ ${ }_{3}^{2}$ Chair Holder of the University of Evora UNESCO Chair \\ ${ }_{3}^{3}$ Associate Professor, Islamic Azad University, Pardis Branch, Tehran, Iran
}

\begin{abstract}
Considering the increasing challenges of the current cities, the urban tourism has been proposed as a solution for solving or minimizing different problems. Including economic, social and environmental aspects, this approach can lead to the fulfillment of sustainable development theory. Accordingly, there is no doubt about the successful results of the urban tourism development and all urban managers and authorities agree on this point. Meanwhile, what threatens the success of the urban tourism development plans is to ignore the all effective factors that make effect on the quality of travel experience. In their best, the cities are projected in their public spaces, and any tourist spent a considerable part of his travel in such spaces. Thus the quality of urban spaces is an important factor on the successfulness of urban tourism development plans and hence their environmental desirability must be studied and evaluated more precise under a comprehensive approach. The main objective of this research is to answer the main question of how the effective spatial qualities on tourism are explain with regard to the social factors. Since the man and his activities are the base of the urban studies, this article uses an urban-strategic approach based on the descriptive-analytical method using library resources to study the social factors that are effective on the qualities of urban spaces. The analytical model of the research will be presented based on the theoretical studies. The results show that some qualities such as flexibility, functional diversity, physical diversity, vegetation, safety, lightening, landscape attractiveness, identity, and memorability in relation to the urban space, and social and arbitrary activities based on Gehl theory can make effect as the complementary factors of the urban tourism attraction and make effect on social factors such as vitality, sense of security, arbitrary activity, social activity and tourists sense of peace. Emphasizing on the social exchange theory, such factors can pave the way for the sustainability of urban tourism industry. The results of this research can be used in identifying and reinforcing the spatial qualities relating to the social factors that are effective on tourism in Iran. Consequently, they can be useful in the tourism development. The essential value of this article is its simultaneous focus on both spatial qualities (physical dimension) and social factors (human dimension) in relation to the tourism development. In this regard, the unidimensional attitude is rejected and the adaptation of a holistic approach to the urban tourism is highlighted.
\end{abstract}

\section{Introduction}

Urban tourism is a growing approach. Although it has a long history, but due to its positive effects on the urban life, today it has attracted more attention. Apart from its effects on the tourists, urban tourism can make considerable effects on the quality of the residents' of tourism destination. Global experiences show that tourism is not based only on the natural and historical attractions but nowadays, in many cases, the man-made environmental desirability is preferred over the old heritage of the touristic host societies. Thus it is necessary to improve the attitude toward urban tourism, and the role of urban spaces as the most important setting of the social interactions between the host and guest societies on one hand and the meaningfulness of the urban space and time for tourists on the other hand. This article first reviews the concepts, theories and opinions on the research keywords with emphasis on case of Iran and then we will present our theoretical framework in order to re-emphasize the role of the quality of urban spaces in urban tourism focusing on the social factors.

\section{The role of social factors in urban tourism}

Paying attention to the sociocultural factors in tourismrelated studies is mainly directed toward the mutual effects of the host society and tourists on each other. In other words, the mentioned factors have the effects that are the result of the touristic activities in the social interactions of the host society and tourists. Emphasizing on the cultural aspect, the cultural effects are the changes 
occurring in the rituals, arts, architecture and spiritual and intellectual values (Saeidnia and Mehdizadeh, 2012: 66). This type of attitude in turn is very important. Orbasl (2000) believes that the sociocultural aspect of the tourists' movement in urban spaces is a very important point in the field of urban tourism because the encounter of the host and guest is the result of cultural differences in using the urban space or the multiplicity of the urban function and diversity of the urban users (Orbasl, 200: 56). In this regard, the fundamental subjects in the urban spaces management that are involved in identification and application of such spaces include the spatial analysis of urban functions and activities, value of the urban uses, transportation models, citizens' mobility and the urban networks that in sum, form the logical order of the urban behaviors (Rabbani and Vahida, 2007: 45).

It is obvious that in touristic activities, different types of cultures and behaviors of the two societies, i.e. the host and guest societies are involved. But the host society has its own goals, values and interests that are expected to be met in the development of touristic activities. Undoubtedly, the mutual reactions between the two cultures and their tacit motivations make different effects and changes. Such effects and changes sometimes are in behalf of the host society and sometimes they act against the host society. Today, new approaches, particularly the approaches toward sustainable tourism development attempt to reinforce the positive values and interests of tourism and reduce its negative effects (Saeidnia and Mehdizadeh, 2012: 67-8). Table 1 shows a part of the most important positive and negative impacts of tourism focusing on the social and cultural aspects.

Since the social context includes culture, religion and ethnicity, particularly in Iran with its considerable diversity of mentioned categories, it seems necessary to pay attention to cultural tourism, religious tourism and ethnic tourism.

\section{Tourism in Iran with emphasis on the social factors}

Iran is a country with many natural, historical, cultural, religious and ethnic attractions and hence the tourism in Iran is potentially ideal. In other words, material and nonmaterial potentials (both natural and man-made ones) are very high in this country. Focusing on the social factors, Iranians are known as warm and hospitable people. Compared to cultural, religious and ethnic tourism, there are little studies on other social factors in this country. Accordingly, in this study we mainly focus on the three mentioned types of tourism.

\subsection{Cultural tourism in Iran}

The recourse of the cultural tourism to both old and contemporary cultural symbols implies the exclusive conditions of Iran in urban tourism. With its old history and civilization, Iran has provided a wide extent for tourists who want to visit and enjoy the glorious history of the country. Cultural masterpieces from the old history of Iran have made Iranian cities such as Isfahan, Yazd,
Shiraz, Kermanshah and Susa famous worldwide, such that the identity of Iran and its cities are tied with the elements and spaces such as Chogha Zanbil in Susa, Naqsh-e Jahan Square in Isfahan, Persepolis and Pasargadae historical sites near Shiraz, Takht-e Soleiman historical site in Takab in West Azerbaijan, Falak-olAflak Castle in Khorramabad, Sultanieh in Zanjan, Bistoun Site in Kermanshah, Traditional Bazaar of Tabriz, Fin Garden in Kashan, Golestan Palace in Tehran, Delgosha Garden in Yazd, etc.

Table 1. Negative and positive sociocultural effects of tourism

\begin{tabular}{|c|c|c|}
\hline $\begin{array}{l}\text { Effective } \\
\text { factors }\end{array}$ & Positive impacts & Negative impacts \\
\hline $\begin{array}{l}\text { Using culture } \\
\text { as an } \\
\text { attraction }\end{array}$ & $\begin{array}{l}\text { - Increase of } \\
\text { supporting the } \\
\text { traditional } \\
\text { culture } \\
\text { - Introducing the } \\
\text { ethnic identity } \\
\text { - Revival the } \\
\text { traditional arts } \\
\text { and rites } \\
\text { - Revival the } \\
\text { local language } \\
\text { and literature } \\
\end{array}$ & $\begin{array}{l}\text { - Changes in the } \\
\text { traditional arts due to } \\
\text { the tourists' tastes } \\
\text { - Influencing the } \\
\text { privacy of traditional } \\
\text { areas } \\
\text { - Crowdedness in the } \\
\text { traditional place } \\
\text { - Commercialization of } \\
\text { the cultural products }\end{array}$ \\
\hline $\begin{array}{l}\text { Direct contact } \\
\text { between } \\
\text { tourists and } \\
\text { local people }\end{array}$ & 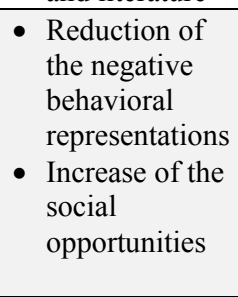 & $\begin{array}{l}\text { - Reinforcement of the } \\
\text { negative behavioral } \\
\text { representations } \\
\text { - Outbreak of new } \\
\text { diseases } \\
\text { - Increase of the } \\
\text { population density } \\
\text { and crowdedness }\end{array}$ \\
\hline $\begin{array}{l}\text { Changes of } \\
\text { social roles } \\
\text { and jobs }\end{array}$ & 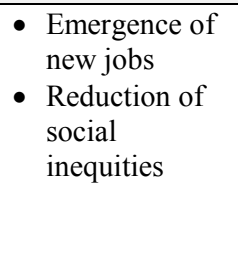 & $\begin{array}{l}\text { - Increase of social } \\
\text { conflicts } \\
\text { - Increase of social } \\
\text { inequities } \\
\text { - Destruction of local } \\
\text { languages and } \\
\text { accents }\end{array}$ \\
\hline $\begin{array}{l}\text { Development } \\
\text { of tourism } \\
\text { bodies }\end{array}$ & $\begin{array}{l}\text { - Increase of } \\
\text { recreational } \\
\text { facilities } \\
\text { - Increase of the } \\
\text { accessibility } \\
\text { facilities } \\
\end{array}$ & $\begin{array}{l}\text { - Limitedness of the } \\
\text { local people's } \\
\text { accesses } \\
\text { - Increase of the } \\
\text { bureaucracy }\end{array}$ \\
\hline $\begin{array}{l}\text { Population } \\
\text { increase due } \\
\text { to the tourism } \\
\text { development }\end{array}$ & $\begin{array}{l}\text { - Increase of the } \\
\text { quality and } \\
\text { quantity of } \\
\text { welfare } \\
\text { facilities } \\
\text { - Increase of the } \\
\text { quality of life }\end{array}$ & $\begin{array}{l}\text { - Increase of the } \\
\text { crowdedness and } \\
\text { population mix } \\
\text { - Increase of the crimes }\end{array}$ \\
\hline
\end{tabular}

On the other hand, focusing on Iranian contemporary culture, the cultural diversity of the country is considerable while the diversity of its subcultures are more important among the other aspects of cultural diversity. In this regard one can refer to the rites and rituals in the subcultures in different regions of the country, specifically in especial events such as Yalda Night. 


\subsection{Religious tourism in Iran}

Due to the diversity of ethnics believing in Islam in Iran, the religious tourism is very common in this country. Some holly places such as the Imam Reza Shrine (the shrine of $8^{\text {th }}$ Shiite Imam) in Mashhad and Fatima Masumeh Shrine in Qom as the religious centers of the country along with the tombs of many Imamzadehs all around the country has made Iran a destination for religious tourists all seasons of the year. Religious ceremonies, particularly the Ramadan, Sha'ban and Muharram months in cities like Zanjan and Niasar are attractive both for religious people and other tourists.

The positive factors of the Iranian religious tourism can be classified as follows (Aqajani and Farahanifard, 2015: 56):

- Very attractive rituals and ceremonies in different regions: different months have different feasts and mourning days when the Iranian of different regions take those ceremonies differently from each other.

- Accommodations: considering the social, cultural and religious diversities, there are diverse hospitality and accommodation facilities in Iran. This factor besides the experience of living in traditional environment is considered as the tourist attraction factors.

- Islamic holy sites: apart from the spiritual characteristics of the Islamic holy sites, these places are indeed the exhibition of arts and symbols of the Islamic culture and civilization that normally attract non-Muslim tourists

- Offering Halal Foods and respecting the prayer times

By contrast, the negative and deterrent factors are as follows (Aqajani and Farahanifard, 2015: 56-8):

- Undesirable information and promotion: promotion and advertisement is a modern way of informing. In order to persuade the target society, the promotions and advertisement must be based on different tools such as written, audio and visual communication tools to make changes in the values, beliefs, attitudes and behaviors of the people. This aspect is weak in Islam world in general and Iran in particular, and there is no precise information about the centers, rituals and plans of religious tourism.

- The weakness in providing the security and financial, physical and mental comfort of the tourists: even a very light sense of insecurity can make irreparable damages on tourism industry (including the religious tourism) of any country. A major obstacle to religious tourism in Islam and Iran is the real or unreal descriptions of conflicts and insecurities at international level. The undesirable and negative effects of Iran-Iraq war is still alive in the minds of the people.

- Undesirability of the amenities: one of the most primary wants of any tourist is to benefit from the accommodation and amenities according the most updated standards of the world. Unfortunately, since the religious tourists mainly root in the poor classes of the society and since they are always willing to pilgrim despite all problems, the attitude toward the quality and quantity of the accommodation and amenities of such tourists are usually weak and neglected.

\subsection{Ethnic tourism in Iran}

The wide span and diversity of the ethnicities in Iran promotes the ethnic tourism in this country. The dispersal of Lor, Kurd, Turk, Balouch, Persian, Turkman and other ethnicities around Iran along with the long roots of their civilization can be really attractive for both Iranian and foreign tourists. This specific type of tourism not only can make those ethnicities closer to each other, but it can revive their historical and traditional rites on one hand and reinforce their social and ethnic structures to support their collective culture and heritage on the other hand. As an example, the traditional rites of Lori and Ilami Chamar Mourning event is one of the most important rituals of this ethnicity with a very long history. The people of this 10 -thousand year old ethnicity has not been attracted to modernity during all the past years, and hence their social and traditional ceremonies, rites and rituals are still alive. Ilam Province people still believe in the values of such rituals of their own land. Chamar is the traditional, objective and theatrical mourning being held in Ilam province of Iran.

\section{Conclusion and Discussion}

Encountering the challenges and problems of the current cities has led to several theoretical and practical attempts. One of the most recent and most comprehensive attempts in this regard is the sustainable development theory focusing on the social, economic and environmental aspects. This theory almost covers all dimensions of the human collective life and creates a logical cycle between the physical, human, and behavioral aspects. Indeed the durability of the cities is not possible without having a comprehensive view to all the mentioned three aspects. Meanwhile, urban tourism is an industry that makes effect on and is effected by the society, economy and environment in the framework on urban sustainability. In terms of the positive impacts of tourism as an environmentally clean industry, there is no doubt about the economic effects (less costs) and social interactions between the host and guest societies. Such factors can lead to considerable positive results if there is a proper planning for them. Considering the social exchange theory, in facing the natural and artificial phenomena (including the cities) human beings always compare their inputs and outputs. Indeed they always do cost-benefit calculations and make their further decisions based on the result of those calculations. In focusing on the subject of urban tourism we accept the social exchange theory and recognize that the satisfactory experiences of tourists depends on several criteria and factors. Although these factors can be general or individual (varying from one person to another or be based on the personal traits) but they play a key role in the durability and sustainability of the urban tourism. This is while the urban spaces are the main point of interaction between the physical and social aspects of the host city and the tourists. The quality of 
such spaces can contribute in the fulfilment of guests' social exchange analysis considerably.

On the other hand, the quality of urban spaces (as the best representation of collective life) cannot be defined as an inherent physical feature independent from the visitor, or as a completely mental and subjective category regardless of the relationship with the physical aspect. Adopting a phenomenological approach we can state that the urban spaces are phenomena that are formed in the interaction of social and physical aspects and are highly effected by the man and his activities. Such a definition requires the simultaneous attention to three components (i.e. the form, meaning and function) of the urban spaces that is the setting for interactions between man and place on one hand and man and other men on the other hand. The environmental desirability of this phenomena encompasses several factors. Table 2 shows a part of attempts being done by some theorists and researchers in relation to the quality of urban public spaces.

Table 2. Quality of urban public space according to different researchers

\begin{tabular}{|l|l|}
\hline Researcher & $\begin{array}{l}\text { Key components implying the quality of } \\
\text { urban space }\end{array}$ \\
\hline $\begin{array}{l}\text { Qalenoei and } \\
\text { Bahrami (2014) }\end{array}$ & $\begin{array}{l}\text { Climatic comfort, comfort and peace, mixed } \\
\text { land uses, social mix, security, pause, high } \\
\text { density, physical diversity, enclosure, } \\
\text { access, permeability }\end{array}$ \\
\hline Handy (2006) & $\begin{array}{l}\text { Density, mixed land uses, availability and } \\
\text { connectedness to communication networks, } \\
\text { regional structure, climatic comfort, shadow } \\
\text { of the environment, aesthetic qualities, place } \\
\text { attractiveness }\end{array}$ \\
\hline $\begin{array}{l}\text { Mohammadi \& } \\
\text { (2012) }\end{array}$ & $\begin{array}{l}\text { Mental perception environment, objective } \\
\text { perception environment, physical quality } \\
\text { environment, security, safety, and } \\
\text { behavioral qualities }\end{array}$ \\
\hline $\begin{array}{l}\text { Project of Public } \\
\text { Space (PPS) }\end{array}$ & $\begin{array}{l}\text { Accessibility and connectedness, comfort } \\
\text { and mental image, application, activities and } \\
\text { sociability }\end{array}$ \\
\hline Gehl (2007) & $\begin{array}{l}\text { Priority of social and optional behaviors } \\
\text { over the compulsory activities }\end{array}$ \\
\hline $\begin{array}{l}\text { London } \\
\text { Planning } \\
\text { Advisory } \\
\text { Committee } \\
\text { (LPAC) }\end{array}$ & $\begin{array}{l}\text { Human scale and intensity of the urban } \\
\text { fabric, suitable structure, readability and } \\
\text { identity, cleanness and safety, desirable } \\
\text { urban management, visual richness, mixed } \\
\text { land uses and activities, existence of public } \\
\text { spaces and especial spaces, and finally the } \\
\text { easiness of walking and driving movements }\end{array}$ \\
\hline $\begin{array}{l}\text { Jacobs (1961) } \\
\text { cited in Yoke } \\
\text { Lai et. al (2013) }\end{array}$ & $\begin{array}{l}\text { Social interactions, vitality, day and night } \\
\text { function, urban security, functional diversity } \\
\text { and attractiveness of the place. }\end{array}$ \\
\hline
\end{tabular}

As the table shows, most theories have emphasized on the role of social factors in the quality of urban spaces. Professional literature of the urban planning shows that such factors can be clarified with the combination of factors like the vitality, security, behavioral patterns and human activities. A significant point is that the space the context and ground of the activities without which no activity is imaginable. Thus the emphasis on the social factors in the discussion of quality desirability of the urban spaces doesn't mean to ignore the physical aspect but it is merely an emphasis on the human centrality in the urban planning and urban tourism development planning. Accordingly, urban tourism is formed in the urban spaces and hence it is affected by the quality of such spaces directly or indirectly. On one hand, the urban tourism is affected by the social factors that can act as attraction, and on the other hand, they can make effect on the social and cultural structures of both host and guest societies. Of course these two types of effects are mutual and it is merely possible to identify the weakness and strength of interactional relationships. The relationships between urban tourism and social factors are illustrated in Fig. 1.

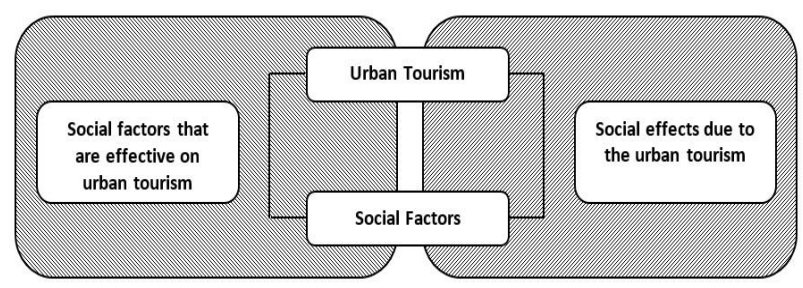

Fig. 1. Mutual relationship between urban tourism and social factors

The humane approach in the urban tourism states that the social and cultural attitude is more important than the economic aspect of tourism. In this approach, the sociocultural factors can be studied at two levels: first, the sociocultural factors, which are indeed a type of social capital of the host society and facilitate this function of urban tourism. Examples of these factors include the social participation, social trust, hospitality, intimate relationship, social solidarity, identity and national (local) sense of pride. Such traits not only can improve the sociocultural conditions of the society, but they play role in the ways of interaction with tourists and creating their satisfaction. For example, the identity and national pride will not let the shortages remain in the tourists' mind as the main features of that place, but the citizens always attempt to create a desirable image of their city for the tourists and make them leave the host city with good memories.

The second level that is proposed in relation to sociocultural factors in the urban tourism is the function of these factors as the destination attractions. As coordinated with the cultural, social and historical heritage, these factors can be investigated under cultural tourism or historical tourism as well. Some of the most important sociocultural factors that are recognized as the urban tourist attractions of Iran are as follows: ritual ceremonies, religious and national ceremonies, unofficial events such as weekly bazaars with emphasis on charities and cultural products, cultural diversity, ethnical diversity, religious diversity, music, local dances and signs, local languages and cloths, and identity symbols with emphasis on social, cultural and historical symbols.

Urban tourism with emphasis on the social factors cannot be fulfilled without paying attention to the cultural, religious and ethnical aspects. In fact the mentioned concept are so inseparably interconnected and form the totality of the social context hand in hand. The professional view to this issue leads us to the 
subcategories of urban tourism including the cultural tourism, religious tourism and ethnical tourism. In light of the quality of urban spaces, the cultural and religious activities and ethnical rites must be classified in terms of Gehl's threefold classification of the feasible activities in urban spaces (Gehl, 1987). Indeed all mentioned aspects (i.e. cultural, religious and ethnical aspects) are parts of social and optional activities and they somehow confirm the fact that undesirable urban spaces cannot be host the tourism events. Fig 2 shows the graphical representation of this claim.

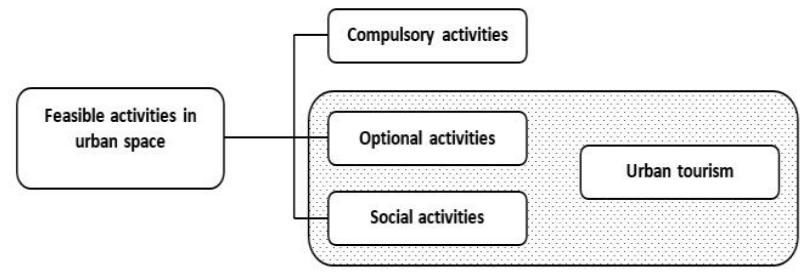

Fig. 2. Feasible activities in urban spaces for tourism

Tourist attraction of each region or city can be manmade or natural. The latter is divided into old and contemporary, and material and intellectual. Iran not only has diverse climates and diverse natural elements (from mountains to deserts, plains, seas and forests) it has very long cultural history, considerable diversity of ethnics, etc. and thus Iran is a desirable potential for the urban tourism development. Indeed with its unique historical, cultural and religious monuments in its different urban regions and old roots of civilization and history on one hand and the modern buildings of its metropolises on the other hand, Iran can introduces many attractions as the old and contemporary man-made elements. This claim is true for the material and intellectual classification of urban tourist attractions as well, while the rites and rituals of different urban subcultures and the diverse religions and ethnics around the country can confirm the mentioned claim.

Focusing on the optional and compulsory activities and the levels of cultural, religious and ethnical tourism in the context of urban spaces, we can propose a model as the proposed analytical model of the research (according to table 3 ) with the aim of studying the spatial qualities that are effective on the urban tourism focusing on the social factors in Iran.

The proposed framework in combination to the urban tourist attractions can make more effects on the development of tourism industry and on the realization of urban tourism potentials in Iran. In other words, paying attention to the spatial qualities in urban design and planning in combination to the social and cultural features can lead to the sustainability of urban tourism processes in a more efficient way.

Table 3. Proposed analytical framework of the research

\begin{tabular}{|l|c|c|c|c|c|}
\hline Urban space & \multicolumn{5}{|c|}{ Social factors } \\
\cline { 2 - 6 } & $\begin{array}{c}\text { Vital } \\
\text { ity }\end{array}$ & $\begin{array}{c}\text { Option } \\
\text { al } \\
\text { activity }\end{array}$ & $\begin{array}{c}\text { Securit } \\
\text { y }\end{array}$ & $\begin{array}{c}\text { Social } \\
\text { activit } \\
\mathrm{y}\end{array}$ & $\begin{array}{c}\text { Comfo } \\
\mathrm{rt}\end{array}$ \\
\hline
\end{tabular}

\begin{tabular}{|l|c|c|c|c|c|}
\hline Flexibility & $*$ & & & $*$ & \\
\hline $\begin{array}{l}\text { Functional } \\
\text { diversity }\end{array}$ & $*$ & $*$ & $*$ & $*$ & \\
\hline $\begin{array}{l}\text { Physical } \\
\text { diversity }\end{array}$ & $*$ & & $*$ & $*$ & \\
\hline Vegetation & $*$ & & & & $*$ \\
\hline Security & & $*$ & $*$ & $*$ & $*$ \\
\hline Lighting & $*$ & $*$ & $*$ & $*$ & $*$ \\
\hline $\begin{array}{l}\text { Landscape } \\
\text { attractiveness }\end{array}$ & $*$ & & $*$ & $*$ & \\
\hline Identity & $*$ & & & & $*$ \\
\hline Memorability & $*$ & & & & $*$ \\
\hline
\end{tabular}

\section{References}

1. Aqajani, Masumeh and Farahani Fard, Saeid, "Religious tourism and its effective factors (case study: Iran)", Strategic Policies Quarterly, No. 9, pp. 43-66 (2015) [in Persian].

2. Rabbani, Rasoul and Vahida, Fereidoon, Urban Sociology, Isfahan: Isfahan University Press and SAMT Pub (2007) [in Persian].

3. Rahimpur, Ali and Seyyed Hosseini, Davood, Landscape of Islamic Tourism, Tehran: Mahya (2000) [in Persian].

4. World Tourism Organization, International Tourism, A Global Perspective, translated by Ali Parsaeian and Mohammad A'rabi, Tehran: Cultural Research Office (1998) [in Persian].

5. Saeidnia, Ahmad and Mehdizadeh, Javad, Urban Tourism (Third Book of Municipality Green Books), Tehran: National Organization of Municipalities (2012) [in Persian].

6. Qalenoei, Mahmood and Bahrami, Maryam, "Evaluating the effective qualities on the urban tourism in Shariati St. of Kerman", Research and Scientific Journal of Iranian Society of Architecture and Urban Planning, No. 7, pp. 23-33 (2014) [in Persian].

7. Mohammadi, Mahmood and Changlavaei, Yunes, "Evaluating the components of urban space quality on the desirability level of touristic walking pathways (case study: prioritization of walking pathways in Isfahan)", Research and Scientific Journal of Iranian Society of Architecture and Urban Planning, No. 5, pp. 15-32 (2012) [in Persian].

8. Handy, S., Self-selection in the relationship between the built environment and walking, Journal of the American planning association, 5 (72), 55- 74. (2006).

9. Gehl, I., Life between buildings, translated by J. Koch, New York (1987).

10. LPAC (London Planning Advisory Committee), London's Urban Environmental Quality, Tibbalds Colbourne Karaski Williams Monro, Remford (1993).

11. Orbaşl, A. Is Tourism Governing Conservation in Historic Towns? Journal of Architectural Conservation 6(3), 7-19 (2000). 
12. Project of Public Space (PPS), How To Turn a Place Around: A Handbook for Creating Successful Public Spaces, Project For Public Spaces, Inc., New York (2001).
13. Yoke Lai, L., Said, I. \& Kubota, A. The Roles of Cultural Spaces in Malaysia's Historic Towns: The case of Kuala Dungun and Taiping, Social and Behavioral Sciences, 85, $602 \quad-25 \quad$ (2013). 